\title{
Using morphometrics to unravel species relationships and delimitations in Sorbus pohuashanensis in the Korean peninsula
}

\author{
Soo-Kyung Park, Hee-Young Gil, Hui Kim ${ }^{1}$ and Chin-Sung Chang* \\ Department of Forest Sciences and The Arboretum, Seoul National University, Seoul 151-921, Korea \\ ${ }^{1}$ Department of Medicinal Plants Resources and Institute of Oriental Medicine Industry, Mokpo National University, Muan-gun 534-729, Korea
}

(Received 29 July 2013; Accepted 29 October 2013)

\section{한반도내 당마가목의 실체와 근연종과의 관계-전형질분석을 중심으로}

\author{
박수경 · 길희영 · 김 휘 ${ }^{1} \cdot$ 장진성* \\ 서울대학교 농업생명과학대학 산림과학부 및 수목원, \\ 1목포대학교 한약자원학과 및 한방산업연구소
}

\begin{abstract}
Subalpine species, Sorbus pohuashanensis in the Korean peninsula, which is assumed to be evolved from hybridization between S. commixta and an unknown species based on the flavonoids data. Morphometric analysis was conducted on the basis of 19 leaf and flower (or fruit) characters. A total of 721 samples in 13 populations of Sorbus pohuashanensis and S. commixta from Korea and additional specimens of S. commixta, S. pohuashanensis, and S. wilsoniana from Japan and China were examined to reveal the hybridization patterns and morphological differences. We found a preliminary evidence where Korean mountain rowan is more related to a Chinese inland taxon, S. wilsoniana, rather than Northeastern Chinese S. pohuashanensis in terms of flavonoids. The current morphological structure of the Korean mountaion rowan, however, which is more similar to $S$. commixta, was neither associated with that of $S$. wilsoniana nor that of $S$. pohuashanensis. This indicates that this morphological variation represents an intermediate of $S$. commixta and $S$. wilsoniana via a more ancient hybridization event in terms of qualitative characters, such as stipules, buds, and carpels. These morphometric differences together with other distinguishing characteristics suggest that the Korean mountain rowan should be considered as a conspecific species of $S$. commixta, although this demonstration of hybridization with the current phenetic species concept contradicts longstanding historical species concept.
\end{abstract}

Keywords: introgressive hybridization, phenetic species concept, Sorbus commixta, Sorbus pohuashanensis, Sorbus wilsoniana, flavonoids, multivariate anaysis,

적 요: 플라보노이드 분석을 실시한 결과 한반도 아고산지역에 널리 분포하는 것으로 추정되는 당마가목 [Sorbus pohuashanensis (Hance) Hedl.]은 중국 내륙에 분포하는 S. wilsoniana, S. amabilis과 동일한 화학형을 보이거나, 혹은 마가목[S. commixta Hedl.]의 화학형이 집단별로 나타나 잡종 가능성이 제기되었다. 따라서, 근연종과 잡종가능성이 제기되는 중국 내륙의 개체들과 당마가목과 마가목 분포지인 한중일의 721 개 개체의 19 개 형질에 대한 다변량분석을 시도하여 분류군의 형태적 분화와 형질에 대한 분석을 시도하였다. 정량적 형질에 대한 단변량과 다변량분석에서 마가목분류군 전체 종간에 뚜렷하게 구분할 수 있는 식별형질은 찾지 못한 반면, 정성형질인 동아의 색, 동아와 잎 뒷면의 털의 색깔 및 유무, 탁엽의 모양의 차이와 심피의 모양 에서 종간 식별 형질을 확인하였다. 형태 분석과 플라보이드 연구 결과, 한반도에 분포하는 한반도당마가목

\footnotetext{
*Author for correspondence: quercus@plaza.snu.ac.kr
}

http://www.pltaxa.or.kr

Copyright (C) 2013 the Korean Society of Plant Taxonomists 
은 중국동북 3성과 극동러시아의 당마가목(S. pohuashanensis)과는 전혀 다른 화학형으로서, 중국 내륙에 분 포하는 S. wilsoniana와 마가목과의 과거 잡종이입에 의한 분류군으로 판단된다. 한반도에 분포하는 추정 교 잡종인 당마가목은 정량적, 정성적으로 마가목과 형태적으로 별다른 차이점을 확인할 수 없어, 역사적 종의 개념(historical species concept)에 의한 신 잡종기재보다는 전형질적 종의 개념(phenetic species concept)에 근 거하여 마가목과 동일종으로 보는 것이 타당하여 마가목의 이명으로 처리하였다.

주요어: 다변량분석, 당마가목, 마가목, 윌슨마가목, 잡종이입, 전형질적 종의 개념, 플라보노이드

장미과(Rosaceae)의 능금아과(Maloideae)에 속하는 마가 목속(Sorbus L.)은 북반구의 아시아, 유럽, 북아메리카에 걸 쳐 분포하며 약 100-200여 종이 보고된다(Krüssmann, 1984; Ohwi, 1984; Robertson et al., 1991; Lu and Spongberg, 2003; McAllister, 2005). 속내에서는 일부 분류군은 잡종이 자주 일어나며 무성생식에 의한 미세종(apomictic microspecies) 이 다수 확인된다(Jauhar and Joshi, 1970; McAllister, 2005).

마가목속의 속 이하 분류체계는 Koehne(1913)이 소엽 수와 턱잎의 특징을 기초로 5 개 군(群, groups)으로 분류하 였지만, Robertson et al.(1991)과 Campbell et al.(2007)은 형 태와 플라보노이드, 분자생물학적 정보를 근거로 Aria, Cormus, Torminaria로 세분하여 기존 Sorbus와 독립된 속으 로 인정하였다. 특히 최근 McAllister(2005)는 협의(sensu stricto)의 개념으로 복엽의 수종만을 Sorbus 속을 보고 열 매의 색깔과 과육 세포에 잡색포(chromoplasts)의 특징을 근간으로 2개 아속(subgenus)을 인정하면서, 어린 가지, 잎, 동아 등의 추가 형질로 11절(section)을 세분하였다.

한반도에 분포하는 복엽의 Sorbus 아속에는 3종으로 Sorbus pohuashanensis (Hance) Hedl.(당마가목), S. commixta Hedl.(마가목), S. sambucifolia Cham.(산마가목)가 해당된다 (Lee, 1980). Sorbus절에 속하는 S. pohuashanensis(당마가목) 는 우리나라 중부 이북지역과 중국, 러시아의 일부 지역에 도 분포하는 반면(Lee, 1980; Charkevicz, 1996; Fu et al., 2003), Commixtae절에 속하는 S. commixta Hedl.(마가목)은 우리나 라 제주도 및 울릉도와 남부지역, 일본의 전 지역과 쿠릴열 도 일부, 러시아의 사할린까지 분포한다 (McAllister, 2005). 한편, 주로 관목형태인 Sambufifoliae절의 S. sambucifolia Cham.(산마가목)은 함경남북도와 극동러시아, 일본에 분 포한다(Kurata, 1971; Lee, 1980; Charkevicz, 1996). 본 연구에 서는 교목성인 당마가목, 마가목과 중국 내륙의 근연종을 마가목분류군(Sorbus commixta complex)으로 지칭한다.

Koehne(1913)은 당마가목을 Sorbus amurensis Koehne로 기 재하였지만, 중국에서 채집된 표본을 근간으로 발표한 Pyrus pohuashanensis Hance(1875)의 조합명, S. pohuashanensis (Hance) Hedl.(1901)가 선취권이 있다. Lu and Spongberg(2003) 에 의하면 당마가목은 때로 S. pohuashanensis의 변종으로 처 리하기도 하지만[S. pohuashanensis var. amurensis (Koehne) Y. L. Chou and S. L. Tung], 대부분 S. pohuashanensis의 이명으로 처리한다. 이와 달리 McAllister(2005)는 S. pohuashanensis는 유럽의 S. aucuparia L.와 별다른 형태적 차이를 찾을 수 없다
고 판단하여 유럽의 아종으로 처리하였다[S. aucuparia subsp. pohuashanensis (Hedl.) McAll.]. 본 연구에서는 당마가목은 $\mathrm{Lu}$ and Sponberg(2003)의 의견을 따라 독립된 종(S. pohuashanensis)으로 간주하였다.

마가목(S. commixta Hedl.)은 일본을 중심으로 극동 러시 아 사할린과 제주도까지 분포하는데, McAllister(2005)는 오직 동아와 소엽의 털(유두상 털, papillous)의 유무와 심 피가 갈라진 정도의 차이로 당마가목(sect. Sorbus)과는 다 른 절(sect. Commixtae)로 판단하였다. 마가목의 근연종은 주로 북미대륙에 분포하지만, 유일하게 동아시아에서는 중국 내륙 동부의 S. amabilis Cheng ex T.T. Yu and K.C. Kuan가 언급된다(McAllister, 2005).

국내 분포하는 마가목속에 대한 플라보노이드 분석을 실시한 결과 마가목과 중국 동북3성과 극동러시아에 분 포하는 당마가목의 경우 모두 flavonol이 확인되는 반면 ('commixta type'), 한반도의 당마가목은 flavonols과 flavones 성분이 모두 확인되어 중국과 일본에 분포하는 당마가목, 마가목과 확연히 다른 화학형을 보였다('wilsoniana type'). 중국 내륙의 모든 종에 대한 추가 플라보노이드 분석을 실 시한 결과 sect. Wilsonianae에 속하는 종(McAllister, 2005)인 S. wilsoniana C.K. Schneid., S. sargentiana Koehne, S. setschwanensis (C.K. Schneid.) Koehne와 sect. Commixtae의 $S$. amabilis에서 wilsoniana type의 화학형이 확인되었다. 따라 서, 한반도에 분포하는 당마가목은 중국 내륙의 종들과 유 사할 뿐만 아니라 마가목에서 확인된 일부 성분이 확인되 어 잡종 가능성이 제기되었다(Gil, 2013).

실제 마가목과 당마가목은 모두 염색체가 동일해서 $(2 \mathrm{n}=34$, MacAllister, 2005), 중국 내륙이나 유럽에서 보고 되는 무성생식(apomixis)에 의한 미세종(microspecies)과 달리 유성생식때문에 잡종 가능성이 매우 높다(Jauhar and Joshi, 1970).

기존 문헌에는(Krüssmann, 1984; Ohwi, 1984; Iwatsuki, 2001; Lu and Sponberg, 2003; McAllister, 2005) 마가목이 다 소 개화기가 느리고 꽃 직경이 약간 크며, 소엽수가 적고 (9-11개) 크기가 작으며, 동아의 털이 거의 존재하지 않으 면서 점성이 존재하는 특징에 의해 당마가목[소엽수는 11-13(15)개]과의 차이가 있다고 알려져 있다.

그러나, 강원도의 태백산, 오대산과 경북 지역의 팔공 산, 지리산, 가야산 집단 등에서 채집된 당마가목, 혹은 마 가목을 관찰한 바에 의하면 아린 표면에 흰 털들이 많이 
발달하면서 검붉은 색을 띄거나 아린 표면에 털이 전혀 없거나, 선단부에 갈색털이 있으면서 밝은 붉은색이거나 녹색을 띈 붉은색이며, 점액물질에 의해 다소 끈적이는 등(Gil, 2013), 동아의 특징으로는 뚜렷하게 구분할 수 없 고 잡종 가능성이 제기된다. 본 연구에서는 잡종과 종간 차이를 보이는 정량적 형질에 대한 조사를 통해 분류학적 논쟁을 해결하고자 시도하였다.

국내 연구에서는 Kim et al.(2007a, 2007b)은 유럽의 $S$. aucuparia L.를 포함한 당마가목, 마가목, 산마가목을 형태 28 개 형질을 이용해 다변량분석과 RAPD, ISSR 등의 DNA 분석을 시도하였다. 이외에 Park et al.(2007), Huh et al.(2007) 은 Kim et al.(2007a, 2007b)과 동일한 재료를 이용하여 RAPD 와 ITS 방법으로 연구를 시도하였는데, 유럽의 S. aucuparia, 지리산(마가목), 계방산(산마가목), 가리왕산(마가목), 울릉 도(당마가목)의 집단을 분석하여 지리산-가리왕산/계방산/ 울릉도/유럽종으로 구분되는 관계를 제시하였다. 그러나, 실제 분석에 남한에 분포하지 않는 산마가목(당마가목으 로 추정)을 포함하였고, 개체별로 채집 지역의 정확한 근원 지를 밝히지 않아 분석 내용을 이해하기 어려울 뿐 만 아니 라, 형태의 다변량분석도 OTUs의 평균값을 사용하여 자료 해석의 문제점을 보여준다. 반면, Kim et al.(2003)에서는 당 마가목과 마가목을 모두 혼용하여 분석해서 역시 종간 문 제점을 확인하기 어렵지만, 잎의 형태적 분석에서 제주도 한라산과 울릉도 집단의 잎의 형태가 다른 분류군들과 뚜 렷함을 제시하여 남쪽 집단이 다소 다름을 확인하였다. 기 존 국내 연구의 문제점은 마가목과 당마가목의 실체와 집 단별 유전적 차이에 대해 명확하게 이해하지 못하고 자료 를 분석하였고, 종간 식별 형질에 대한 규명보다는 단순히 집단간(혹은 종간) 차이에만 초점을 맞추어 종의 실체를 이 해하는데 별다른 도움을 주지 못한다는 것이다.

본 연구의 목적은 한반도에 분포하는 당마가목, 마가목, 중국 내륙의 근연종의 형태적인 분석을 통해 전체 관련 분류군의 형태적 분화와 형질에 대한 연구를 시도하고자 한다. 특히, 한반도에 분포하는 당마가목은 마가목과 구 분되는 형질이 존재하는지와 중국 내륙에 분포하는 근연 종과는 어떤 형태적 차이가 있는지 정량적 형질의 다변량 분석과 정성적 형질에 대한 상호비교를 시도하였다. 기존 의 165 개의 잡종이입 연구 사례(Howard, 1993)에서 보듯, 잡종이입은 매우 다양하면서 복잡한 결과가 도출되는데, 본 연구에서는 잡종연구에 대해서는 비교적 제한적 연구 방법인 플라보노이드 분석을 이용해 한중일 3 개국 분포 종을 대상으로 연구 결과를 도출해 추후 분자분류학적 연 구를 위한 가설을 설정하고자 한다.

\section{재료 및 방법}

연구재료: 마가목(Sorbus commixta)과 당마가목(S. pohuashanensis)은 2010년과 2011년, 2년간 국내 13개 집단
에서 채집을 실시하였으며 개화기 표본 330개, 결실기 표 본 391개를 채집하여 조사하였다. 확보된 표본은 서울대 학교 농업생명과학대학 수목원 수우(樹友)표본관(SNUA) 에 보관하였다. 채집은 개화기인 5월 중순-6월 중순, 그리 고 결실기인 8월말-9월말에 걸쳐 실시하였고, 개화기 표 본과 결실기 표본으로 나누어 확보하였다. 확보된 개체 중에는 봄과 가을에 모두 동일 개체에서 채집한 경우나, 혹은 다른 개체에서 확보된 표본으로 구성되나 형질분석 은 각각 독립적으로 시도하였다. 기존의 표본관(樹友, SNUA)에 소장된 표본을 추가하여 분석에 사용하였다.

일본 마가목(S. commixta)은 동경대학(東京大學) 표본관 (TI)과 동경도립 대학(東京道立大學) 표본관(MAK), 경도 대학(京都大學) 표본관(KYO), 동북대학(東北大學) 표본 관(TUS)에 소장된 표본을 중심으로 활용하였고, 중국 동 북 3성(길림, 요녕, 흑룡강) 지역의 당마가목(S. pohuashanensis)과 중국 사천, 섬서 및 산서 내륙의 S. wilsoniana, 중 국 남동부의 S. amabilis 는 중국 북경중국과학기술원(北京 中國科學技術院, Academia Sinica. Beijing) 표본관(PE)에 소장된 표본을 중심으로 조사하였다(Gil, 2013).

형태 분석을 위해 마가목과 당마가목은 지역적인 분포 와 화학형에 근거하여 분석단위(operational taxonomic unit, 이하 OTU)를 설정하였다. 한반도에 분포하는 분류군은 화학형을 근간으로 마가목의 경우 일본에 분포하는 전체 집단 이외에 제주도와 덕유산, 지리산, 가야산 지역의 표 본을 하나의 OTU로 구분('commixta type')하였으며, 당마 가목 중 한반도에서 마가목으로 분류한 이외 전체 집단 ('wilsoniana type')을 '한반도당마가목'으로 규정하였다. 반 면, 중국 동북3성(지린성, 랴오닝성, 헤이룽장성)과 극동 러시아 및 백두산까지 분포하는 분류군('commixta type') 을 '당마가목'으로 하였다. 따라서, 본 연구에서 형태 분석 한 국내 OTUs는 크게 마가목, 한반도당마가목, 당마가목 등 3 개의 OTUs로 정리하였고, 화학형이 일치하면서 근연 관계로 알려진 중국 내륙의 사천, 섬서 및 산서의 $S$. wilsoniana(이하 윌슨마가목)와, 중국 남동부에 분포하는 S. amabilis도 형태 분석에 포함시켰다. 또한, 과거 울릉도 개체가 교목성이면서 동아나 잎의 크기, 소엽 수와 크기, 화서, 꽃 및 열매의 크기가 모두 커서 새로운 종일 가능성 이 제기되어(Nitzelius, 1989), 본 연구에서는 다른 OTU로 설정하여 분석을 실시하였다.

형태분석: 전체 13 개 집단(Fig. 1)에서 채집한 개화기 표 본 330 개, 결실기 표본 391 개를 이용하여, 국내 2 개의 OTU(마가목, 한반도당마가목)에 대해 기존 언급된 형질 과 직접 표본을 관찰하며 추가한 형질을 중심으로 조사하 였다. 외국 기관에 소장된 표본은 국내 채집 표본과 상호 비교 분석을 위해서 주로 결실기 표본을 중심으로 잎 14 개, 화서 및 열매 7 개와 1 개의 형질 간 비율을 추가하여 총 22 개의 형질을 사용하였다.

외국 생체 채집이 불가능해서 개화기 표본에서는 국내 


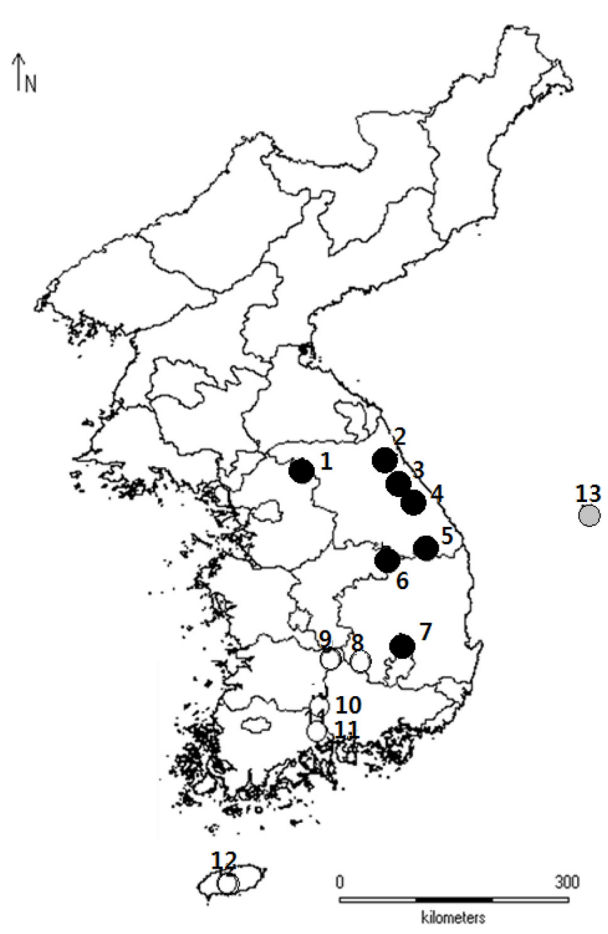

Fig. 1. Collection sites of Sorbus pohuashanensis and S. commixta in Korea. : S. pohuashanensis (1 Mt. Hwaak 2 Mt. Seorak 3 Mt. Odae 4 Mt. Balwang 5 Mt. Taebaek 6 Mt. Sobaek 7 Mt. Palgong) O: S. commixta 8 Mt. Gaya 9 Mt. Deogyu 10 Mt. Jiri 11 Mt. Baekun 12 Mt. Halla; $\bigcirc: 13$ Ulleung Island.

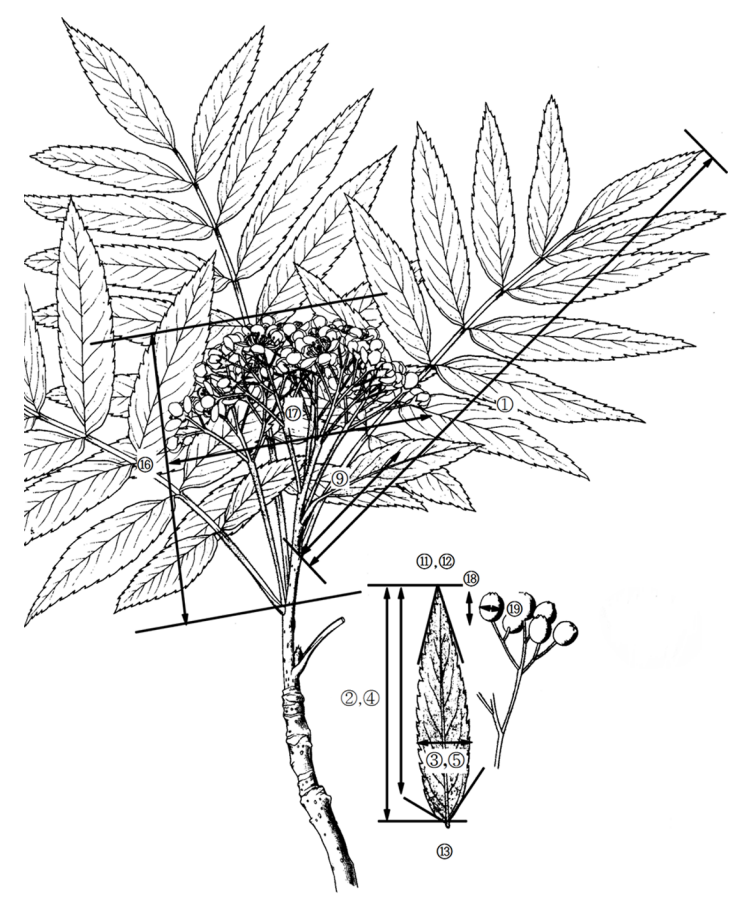

Fig. 2. Diagram of leaf and pome characters measured for numerical analysis. Numbers correspond to character number in Table 1 (Illustration from Nakai, 1916).
Table 1. Morphological characters for flowers with leaves (A) and pome with leaves (B) of the Sorbus commixta complex. Units of measurement are given in parentheses.

\begin{tabular}{|c|c|}
\hline \multicolumn{2}{|c|}{ A. Morphological characters of leaves and flowers } \\
\hline A. & Leaf length $(\mathrm{mm})$ \\
\hline B. & Terminal leaflet length (mm) \\
\hline C. & Terminal leaflet width $(\mathrm{mm})$ \\
\hline D. & Middle leaflet length (mm) \\
\hline E. & Middle leaflet width (mm) \\
\hline F. & Petiole length of terminal leaflet (mm) \\
\hline G. & Rachis length (mm) \\
\hline H. & Petiole length (mm) \\
\hline I. & Number of leaflets \\
\hline J. & Angle of leaflet apex, terminal leaflet $\left({ }^{\circ}\right)$ \\
\hline $\mathrm{K}$. & Angle of leaflet apex, middle leaflet $\left({ }^{\circ}\right)$ \\
\hline $\mathrm{L}$. & Angle of leaflet base, terminal leaflet $\left({ }^{\circ}\right)$ \\
\hline M. & Number of middle leaflet tooth \\
\hline N. & Toothed length, middle leaflet $(\mathrm{mm})$ \\
\hline O. & Length of corymb (mm) \\
\hline P. & Diameter of corymb (mm) \\
\hline Q. & Diameter of flower (mm) \\
\hline R. & Length of petal (mm) \\
\hline S. & Width of petal (mm) \\
\hline $\mathrm{T}$. & Length of calyx-tube (mm) \\
\hline $\mathrm{U}$. & Width of calyx-tube (mm) \\
\hline $\mathrm{V}$. & Number of stamens \\
\hline W. & Length of stamen (mm) \\
\hline $\mathrm{X}$. & Number of carpels \\
\hline Y. & Length of pistile (mm) \\
\hline $\mathrm{Z}$. & Ratio of toothed length/leaflet length, middle leaflet \\
\hline \multicolumn{2}{|r|}{ B. Morphological characters of leaves and fruits } \\
\hline$A^{\prime}$. & Leaf length $(\mathrm{mm})$ \\
\hline B'. & Terminal leaflet length $(\mathrm{mm})$ \\
\hline $\mathrm{C}^{\prime}$. & Terminal leaflet width (mm) \\
\hline D'. & Middle leaflet length (mm) \\
\hline E'. & Middle leaflet width (mm) \\
\hline$F^{\prime}$. & Petiole length of terminal leaflet (mm) \\
\hline G'. & Rachis length (mm) \\
\hline H'. & Petiole length $(\mathrm{mm})$ \\
\hline I'. & Number of leaflets \\
\hline J'. & Angle of leaflet apex, terminal leaflet $\left({ }^{\circ}\right)$ \\
\hline K'. & Angle of leaflet apex, middle leaflet $\left({ }^{\circ}\right)$ \\
\hline
\end{tabular}


Table 1. Continued

\begin{tabular}{cl}
\hline \hline L'. & Angle of leaflet base, terminal leaflet $\left(^{\circ}\right)$ \\
M'. & Number of middle leafletís tooth \\
N'. & Toothed length, middle leaflet $(\mathrm{mm})$ \\
O'. & Length of corymb $(\mathrm{mm})$ \\
P'. & Diameter of corymb $(\mathrm{mm})$ \\
Q'. & Length of pome $(\mathrm{mm})$ \\
R'. & Diameter of pome $(\mathrm{mm})$ \\
S'. & Number of seeds \\
T'. & Length of seed $(\mathrm{mm})$ \\
U'. & Width of seed (mm) \\
V'. & Ratio of toothed length/leaflet length, middle leaflet \\
\hline
\end{tabular}

채집 표본만을 중심으로 잎 14 개, 화서 및 꽃 11 개의 형질 과 1 개의 형질 간 비율 등 총 26 개의 형질에 대한 단변량분 석만을 실시하였다(Table 1). 형질 측정을 위한 잎은 대표 적인 잎(가장 크기가 큰 잎을 중심)을 측정하였으며, 가운 데 소엽은 잎의 가운데 위치하는 가장 큰 소엽을 기준으 로 선택하였다.

다변량분석에 사용할 수 없는 동아의 색깔, 동아의 털, 동아의 털 색깔, 및 동아 표면의 털의 특징 등 4 개의 정성 적 형질은 따로 관찰 기록하였다. 특히, 동아 표면 털의 특 징은 동아 전체에 밀생하거나 혹은 정단 부분만 밀생하는 특징이 분류군마다 다른 것으로 알려져 있어(McAllister, 2005) 1)털이 없음, 2)동아 선단부 및 아린의 끝 부분만 밀 생, 3)동아 표면 전체에 밀생 등 세 가지 유형으로 나누어 조사하였다.

각 형질의 종간 혹은 종내 변이의 분석을 위해 통계 분석 프로그램으로 XLSTAT과 R-package(version 2.15.2)을 이용 하여 단변량분석과 다변량분석을 실시하였다. 다변량분 석으로는 상관행렬(correlation matrix)을 이용하여 주성분 분석(principal components analysis, PCA)을 시도하였다

\section{결 과}

한반도당마가목과 마가목의 정량 형질 분석: 두 종간의 단변량분석을 실시한 결과, 한반도당마가목은 마가목보 다 잎길이(형질 $\mathrm{A})$, 정단 소엽 길이(형질 $\mathrm{B})$, 화서 직경(형 질 $\mathrm{P})$, 열매 직경(형질 $\left.\mathrm{Q}^{\prime}\right)$ 에서 변이가 일부 중첩되지만 다 소 큰 것을 확인하였다. 한편, 열매 직경(형질 Q')은 덕유 산 집단과 가야산 집단 모두 한반도당마가목과 마가목과 중첩되는 변이를 보였다(Fig. 3, F).

국내에서 직접 채집한 생체에서 꽃 직경(형질 $\mathrm{Q}$ ), 꽃잎 길이(형질 $\mathrm{R})$, 꽃잎 너비(형질 $\mathrm{S})$, 꽃받침통 너비(형질 $\mathrm{U}$ ), 결실기 표본에서 종자 길이(형질 T') 및 너비(형질 U')를 측정하였는데, 종자 길이가 한반도당마가목이 마가목보
A.

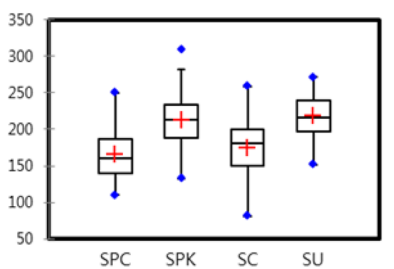

C.

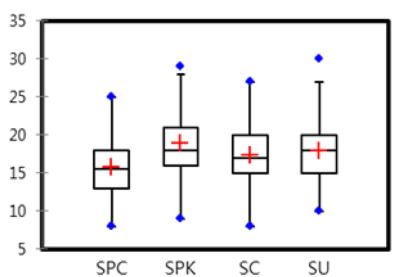

E.

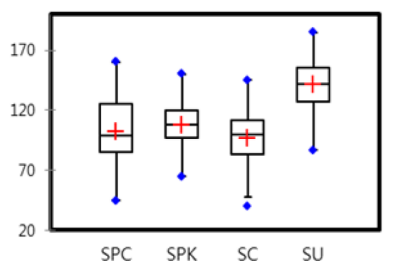

B.

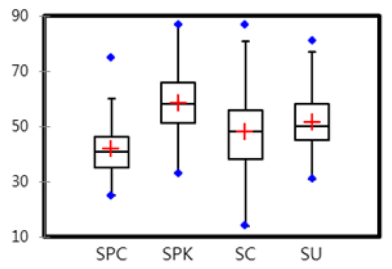

D.

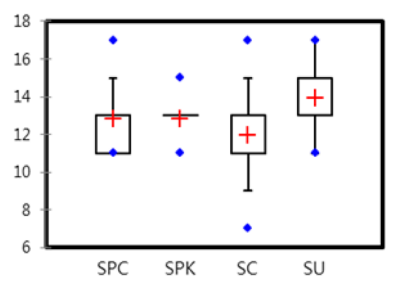

F.

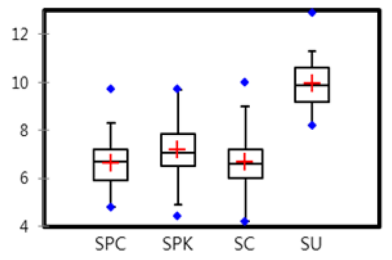

Fig. 3. Values for the discriminating characters for leaves with pomes of the Sorbus commixta complex. Acronyms: SPC, S. pohuashanensis [China]; SPK, S. pohuashanensis [Korea]; SC, S. commixta; SU, Ulleung population of S. commixta. A, Leaf length $(\mathrm{mm})$; B, Terminal leaflet length $(\mathrm{mm})$; C, Terminal leaflet width (mm); D, Number of leaflets; E, Diameter of corymb (mm); F, Diameter of pome $(\mathrm{mm})$.

다 컸으며, 그 외의 형질에서는 두 분류군간 차이가 없었 다. 그러나, 기존에 종으로 인정된 울릉도 집단의 개체에 서는 잎의 길이, 소엽의 수, 열매의 크기에서 다른 분류군 들과 차이가 확인되었다(Fig. 3).

총 22 개 형질 중 상관관계가 서로 높은 3 개의 형질 [정단 소엽 길이(형질 $\mathrm{B})$, 가장 큰 소엽 길이(형질 $\mathrm{D})$, 엽축 길이( 형질 $\mathrm{G})]$ 를 제외한 19 개 형질을 이용하여 주성분분석을 실시하였다(Table 2). 주성분 축(PC) 1, 2와 3은 각각 $36.13 \%, 14.95 \%, 11.51 \%$ 로서 이 중 PC 1 이 가장 높았으며, 3 개의 성분 eigenvalue 누적비율은 $62.59 \%$ 였다. 주성분분 석에서 $\mathrm{PC} 1$ 과 높은 상관관계를 보이는 형질로는 잎길이( 형질 $\left.\mathrm{A}^{\prime}\right)$, 정단 소엽 길이(형질 $\left.\mathrm{B}^{\prime}\right)$, 정단 소엽 너비(형질 $\left.\mathrm{C}^{\prime}\right)$, 정단 소엽의 엽병 길이(형질 $\left.\mathrm{F}^{\prime}\right)$, 엽병 길이(형질 $\left.\mathrm{H}^{\prime}\right)$, 가장 큰 소엽의 거치 부분 길이(형질 N'), 화서 길이(형질 $\left.\mathrm{Q}^{\prime}\right)$, 화서 직경(형질 $\left.\mathrm{P}^{\prime}\right)$ 으로서 잎과 화서 및 열매의 크기 와 관련된 형질이었다. PC 2 에서는 정단 소엽 엽두 각도( 형질 J'), 정단 소엽 엽저 각도(형질 L')와 높은 상관관계를 보였으며, $\mathrm{PC} 3$ 에서는 가장 큰 소엽 엽신의 거치 비율(형 질 Z')과 높은 상관관계를 보였다.

주성분분석 결과 대부분의 한반도당마가목과 마가목 
Table 2. Loadings of the first three principal components for 15 characters from the analysis of 429 individuals of Sorbus commixta complex, S. wilsoniana, S. amabilis, S. pohuashanensis [Korea]. Character numbers correspond to those in Table 4.

\begin{tabular}{cccc}
\hline \hline \multirow{2}{*}{ Character No. } & \multicolumn{3}{c}{ Components } \\
\cline { 2 - 4 } 1 & 1 & 2 & 3 \\
\hline 2 & 0.901 & -0.248 & -0.050 \\
3 & 0.767 & 0.103 & 0.046 \\
6 & 0.641 & 0.115 & 0.593 \\
8 & 0.575 & 0.221 & 0.288 \\
9 & 0.680 & -0.334 & 0.133 \\
10 & 0.409 & -0.445 & -0.395 \\
11 & -0.140 & -0.042 & 0.794 \\
12 & -0.109 & -0.295 & 0.745 \\
13 & 0.220 & 0.131 & 0.538 \\
14 & 0.379 & 0.742 & -0.021 \\
15 & 0.751 & 0.548 & -0.139 \\
16 & 0.754 & -0.276 & -0.174 \\
17 & 0.717 & -0.259 & -0.072 \\
19 & 0.500 & -0.151 & -0.177 \\
Eigenvalue & 0.073 & 0.863 & -0.114 \\
\hline Cumulative \% of & 3.896 & 2.310 & 2.188 \\
\hline eigenvalue & 32.64 & 48.03 & 62.62 \\
\hline
\end{tabular}

집단들이 중심에 중첩되었지만, 제주도 한라산 집단만 $\mathrm{PC} 1$ 에 의해 다른 집단들과 뚜렷하게 구분이 되었다. $\mathrm{PC1}$ 은 주로 잎, 화서, 열매 등 형질의 크기와 상관관계가 높아 서, 다변량분석에서 전체적으로 형질의 크기가 작은 한라 산 마가목 집단이 비교적 다른 분류군과 차이를 보인 것 으로 나타났다(Fig. 4). 주성분분석 중 울릉도 집단의 경우 에는 잎과 화서의 크기과 관련된 형질 $\mathrm{PC} 1$ 에 의해 구분이 되어 과거 신종 가능성에 대한 주장(Nitzelius, 1989)을 지 지하였다.

중국내륙종과 한반도당마가목과의 정량형질 분석: 한 반도당마가목, 마가목, 중국 내륙의 윌슨마가목과 $S$. amabilis 4개 OTUs들 간의 형질을 비교한 결과 윌슨마가 목은 소엽수 (11)13-15(17)개, 화서직경 (8)11.1-14.8(18)cm 로 다른 분류군보다 더 많은 소엽수와 큰 화서를 가졌다. 반면, S. amabilis는 오히려 한반도당마가목보다 형태적으 로 작은 특징을 보여 전체적으로 한반도당마가목은 윌슨 마가목과 마가목의 중간형이었다.

총 19개 형질 중 피어슨 상관계수 행렬(Pearson's correlation matrix)에 의해 상관관계가 서로 높은 4 개의 형 질가장 큰 소엽 길이(형질 $\mathrm{D})$, 가장 큰 소엽 너비(형질 $\mathrm{E})$, 엽축 길이(형질 $\mathrm{G})$, 열매 직경(형질 $\left.\mathrm{Q}^{\prime}\right)$ ]은 제외하고 15 개

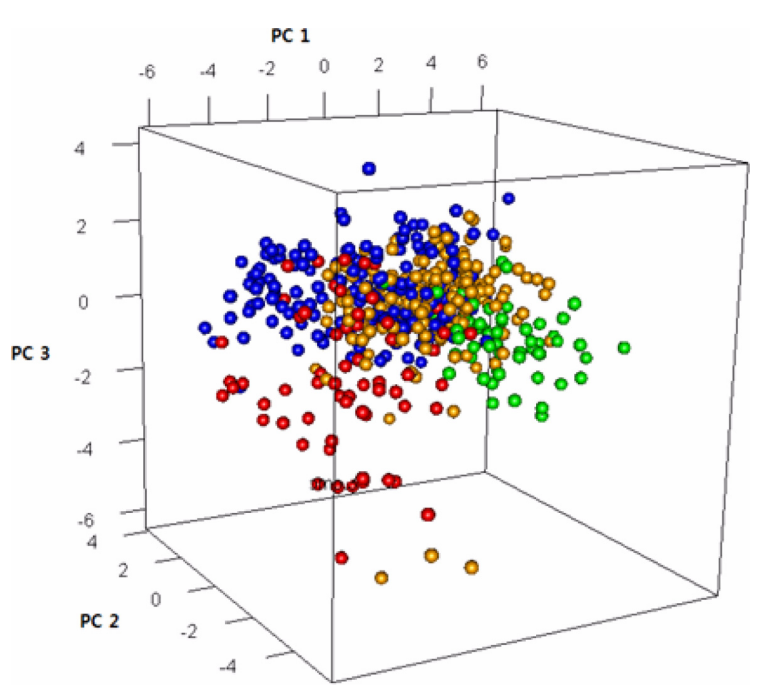

Fig. 4. Three dimensional scatter diagrams from PCA for leaves with pomes of the Sorbus commixta complex. Taxon colours are as follows : S. pohuashanensis [China] (Red); S. pohuashanensis [Korea] (Yellow); S. commixta (Blue); Ulleung population of $S$. commixta (Green).

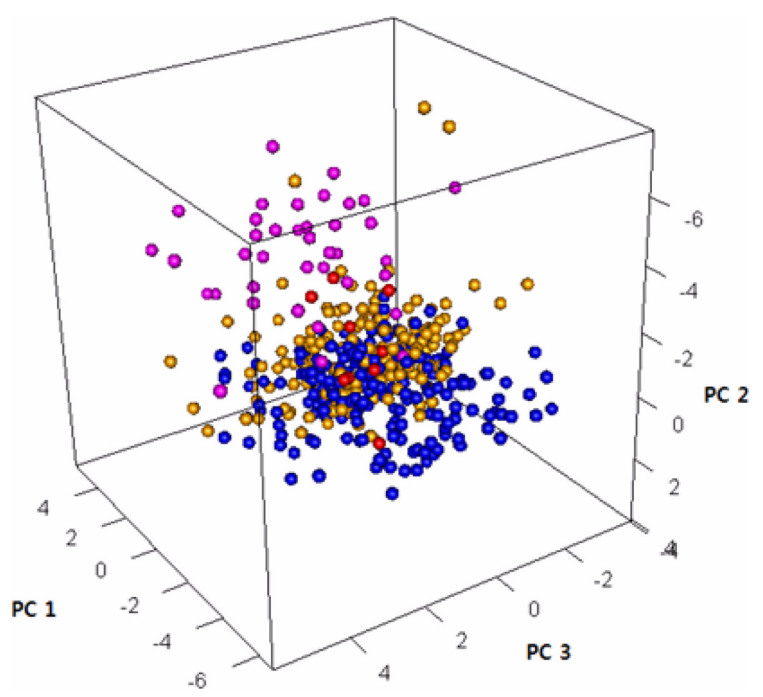

Fig. 5. Three dimensional scatter diagrams from PCA for leaves with pomes of the Sorbus commixta complex. Taxon colours are as follows : S. wilsoniana (Pink); S. amabilis (Red); S. pohuashanensis [Korea] (Yellow); S. commixta (Blue).

형질을 이용하여 주성분분석을 실시하였다. 주성분 축 (PC) 1,2 와 3 은 각각 $32.64 \%, 15.39 \%, 14.59 \%$ 로서 이중 주 성분 축(PC) 1 이 가장 높았으며(Table 3), 3개의 성분 eigenvalue 누적비율은 $62.62 \%$ 였다. PCA에서 PC 1과 높은 상관관계를 보이는 형질로는 잎길이(형질 $\mathrm{A})$, 정단 소엽 길이(형질 $\mathrm{B})$, 정단 소엽 너비(형질 $\mathrm{C})$, 정단 소엽의 엽병 길이(형질 $\mathrm{F})$, 엽병 길이(형질 $\mathrm{H})$, 가장 큰 소엽의 거치부 분 길이(형질 $\mathrm{N})$, 화서 길이(형질 $\mathrm{O})$, 화서 직경 (형질 $\mathrm{P})$ 으 로 잎과 화서의 크기와 관련된 형질이었다. $\mathrm{PC} 2$ 에서는 가 
Table 3. Comparisons about qualitative characters of the Sorbus commixta complex.

\begin{tabular}{|c|c|c|c|}
\hline \multirow{2}{*}{ Taxon } & \multicolumn{3}{|c|}{ Characters } \\
\hline & Buds & Stipules & Carpels \\
\hline $\begin{array}{l}\text { S. pohuashanensis } \\
\text { [China] }\end{array}$ & $\begin{array}{c}\text { Dark brown to } \\
\text { blackish } \\
\text { White hairy } \\
\text { Not sticky }\end{array}$ & $\begin{array}{l}\text { Fan shape } \\
\text { Persistent }\end{array}$ & Free \\
\hline $\begin{array}{l}\text { S. pohuashanensis } \\
\text { [Korea] }\end{array}$ & $\begin{array}{l}\text { Red to blackish } \\
\text { Glabrous to } \\
\text { brown pubescent } \\
\text { apically } \\
\text { Rarely sticky }\end{array}$ & $\begin{array}{c}\text { Needle } \\
\text { shape } \\
\text { Caduceus }\end{array}$ & $\begin{array}{l}\text { Separate but } \\
\text { fused basally }\end{array}$ \\
\hline S. commixta & $\begin{array}{l}\text { Red or greenish- } \\
\text { red } \\
\text { Glabrous or } \\
\text { brown pubescent } \\
\text { apically } \\
\text { Not sticky to very } \\
\text { sticky }\end{array}$ & $\begin{array}{c}\text { Needle } \\
\text { shape } \\
\text { Caducous }\end{array}$ & $\begin{array}{l}\text { Separate but } \\
\text { fused basally }\end{array}$ \\
\hline S. wilsoniana & $\begin{array}{c}\text { Reddish brown } \\
\text { Glabrous or } \\
\text { brown pubescent } \\
\text { apically } \\
\text { Very sticky }\end{array}$ & $\begin{array}{l}\text { Fan shape } \\
\text { Persistent }\end{array}$ & Fused \\
\hline S. amabilis & $\begin{array}{c}\text { Dark reddish } \\
\text { brown } \\
\text { Brown pubescent } \\
\text { apically } \\
\text { Not sticky to } \\
\text { sticky }\end{array}$ & $\begin{array}{l}\text { Fan shape } \\
\text { Persistent }\end{array}$ & \\
\hline
\end{tabular}

장 큰 소엽 엽연의 거치 수(형질 M)와 가장 큰 소엽의 엽연 거치 비율(형질 Z)과 높은 상관관계를 보였으며, PC 3에서 는 정단 소엽 엽두의 각도(형질 $\mathrm{J}$ ), 가장 큰 소엽 엽두의 각 도(형질 K)와 높은 상관관계를 보였다(not shown).

주성분분석 결과 가장 큰 소엽 엽연의 거치 수(형질 $\mathrm{M}$ ) 와 가장 큰 소엽의 엽연 거치 비율(형질 Z)과 상관관계가 높은 $\mathrm{PC} 2$ 에 의해 윌슨마가목과 다른 분류군들과 구분되 었다. 한반도당마가목, 마가목, S. amabilis는 개체들이 대 부분 중첩되어 분류군별로 뚜렷하게 구분을 할 수 없지만 중국 내륙에 분포하는 S. amabilis가 한반도당마가목과 형 태적으로 매우 유사하였다. 단변량분석과 같이 한반도당 마가목은 중국 내륙의 윌슨마가목과 마가목 개체들 사이 에 이 위치하여 두 분류군의 중간 형태임을 확인하였다.

마가목 분류군(S. commixta complex)의 정성적 형질 비 교: 당마가목은 동아가 검은 색이고, 동아 표면과 소엽 뒷 면에 흰 털이 밀생하는 반면(Lu and Spongberg, 2003; McAllister, 2005), 마가목은 동아가 붉은색이면서 털이 대 부분 없으나 가끔 선단부에 갈색털이 나며 다소 끈적이고, 소엽 뒷면에는 털이 없다(Ohwi, 1984; McAllister, 2005). 이
외에 마가목은 심피는 분리되어 있지만 밑부분이 약간 합 쳐져 있어 심피가 완전하게 갈라지는 당마가목과는 구분 된다. 또한, Lu and Spongberg(2003)는 중국에 분포하는 분 류군을 구분하는 형질중 탁엽의 모양이 부채꼴이면서 숙 존하는 탁엽모양과 침형이면서 조기 탈락하는 탁엽 형태 를 가진 분류군로 나누고 있다. 윌슨마가목, S. amabilis, 당 마가목(S. pohuashanensis)은 모두 부채꼴이면서 숙존성 탁 엽인 반면, 마가목(S. commixta)은 침형이며 일찍 탈락하 는 탁엽을 갖고 있다.

동아 색깔에서는 한반도당마가목은 붉은색에서 검은 색으로 다양하지만 대부분 검붉은색을 띄고 있는 반면, 마가목은 빨강고 털이 대부분 없으나 가끔 선단부에 갈색 털이 있다. 한반도당마가목의 동아 표면 털은 털이 전혀 없는 경우, 동아 선단부 및 아린의 끝 부분에만 털이 밀생 하는 경우, 혹은 동아 표면 전체에 밀생하는 세 가지 유형 이 모두 관찰되었지만, 대부분 동아 선단부 및 아린의 끝 부분에만 털이 나타나는 특징을 나타냈다. 털의 색은 대 부분이 갈색이었으며 일부 드물게 갈색과 흰색털이 같이 나타나는 경우가 관찰되어 변이가 심했다(Table 3).

한반도당마가목의 소엽 뒷면에는 마가목처럼 털이 거 의 없어 당마가목보다는 마가목에 가까운 털의 특징을 보 였다. 심피도 모두 분리되면서 밑부분만 융합되어 마가목 과 같은 유형을 보였다(Table 3).

형태적 증거 자료: 중국 동북 3성(한반도내 개체들을 제 외)의 당마가목과 일본의 마가목의 종간 정량적 형질을 분석한 결과 정단 소엽의 크기 외에 두 분류군을 구분할 수 있는 뚜렷한 식별 형질은 없었다(Gil, 2013). 그러나, 울 릉도 개체의 경우에는 꽃, 열매, 화서, 잎의 특징들이 한반 도와 일본, 중국에 분포하는 분류군들과 불연속 변이를 보임을 확인하여, 울릉도 개체의 신종 기재와 특징은 별 개의 연구 논문으로 발표하였다(Park et al., 2013, in press).

한편, 덕유산, 가야산과 지리산 등지의 집단 화학형은 마가목형(commixta type)을 가지면서 형태적으로는 한반 도당마가목과 가까운 중간형을 띄는 집단으로 교잡 가능 성이 높았지만, 특히 덕유산 집단이 단변량분석과 주성분 분석 모두 한반도당마가목에 보다 가깝게 나타났다. 화학 형을 배제하고 형태 형질로 분석한 12 개 집단중 제주도 집단만이 다른 집단과 형태적으로 뚜렷하게 구분되어 마 가목임을 확인할 수 있었지만 그 이외는 대부분이 중첩되 어 종간 구분이 불가능하였다. 그러나, 전형질적 분석에 서는 한반도당마가목은 마가목과 중국 내륙종인 윌슨마 가목의 중간에 위치하며(Fig. 5) 각 형질 분석에서 확인되 지 않은 중간 형태는 간접적으로 확인이 가능하였다.

정성적 형질 중 탁엽의 모양은 McAllister(2005)의 분류 체계에서 서로 다른 절의 분류군에서 확인되어 계통학적 형질로 보기는 어렵지만, 중간형이 없는 2 개 유형으로 구 분되어 식별 형질로는 유용하다. 윌슨마가목, S. amabilis, 당마가목(S. pohuashanensis)은 모두 부채꼴이면서 숙존성 
탁엽인 반면, 마가목(S. commixta)은 침형이며 일찍 탈락 하는 탁엽을 갖고 있다. 한반도당마가목의 탁엽은 침형이 면서 일찍 탈락하는 형태로서 마가목과 동일한 형태이다.

한반도당마가목이라는 실체에서는 동아와 잎의 털의 특징은 윌슨마가목이나 마가목에서 확인되는 형태가 모 두 나타났다(동아 표면의 털은 없거나, 동아 선단부 및 아 린의 끝 부분에만 털이 밀생, 혹은 동아 표면 전체에 밀생). 소엽 뒷면에서는 마가목처럼 털이 거의 없지만, 가끔 일 부 개체에서는 여름까지 털이 존재하여 과거 이 특징으로 변종기재가 된 적도 있다(Sorbus commixta var. pilosa Nakai, Nakai, 1916).

따라서, 한반도당마가목은 정량형질에서도 중국 내륙( 윌슨마가목)이나, 혹은 중국 동북 3 성과 극동러시아 지역 에 분포하는 종(당마가목)의 특징이 일부 확인되지만, 탁 엽의 특징과 털의 여러 특징은 일본과 사할린에 분포하는 마가목에 더 가까웠다.

화학적 증거 자료: 한반도당마가목의 경우 특징적인 두 모종(S. commixta x S. wilsoniana)의 화학형이 복합적으로 모두 나타나면서(chemical complementation) 잡종일 가능 성을 보였다(Gil, 2013).

과거 잡종과 관련된 플라보노이드 연구 결과를 보면 2 가지 유형이 확인된다. 첫 번째 유형은 Baptisia형으로 두 모종(parental species)의 서로 다른 화학형이 F1에서 합쳐 져 모두 확인되는 경우이며(Harborne and Turner, 1984; Giannasi and Crawford, 1986), 두 번째 유형은 Rhododendron 형으로 F1에서 유전적인 불화합성 때문에 플라보노이드 생합성이 무너져 성분이 전혀 발현이 안 되거나 제 3 의 성 분이 나타나는 경우였다(King, 1977; Giannasi and Crawford, 1986). 한반도내 당마가목은 전자인 Baptisia의 특징이 확인되지만, 멕시코 자연집단의 Coreopsis형처럼 $\mathrm{F} 1$ 혹은 F2가 모종과 역교배(backcross)가 되면서 (Crawford, 1970; Giannasi and Crawford, 1986), 형태적으로 는 모종과 동일하지만 화학적으로는 잡종의 형태를 보이 는 경우에 더 가깝다고 본다. 즉, 화학적으로 가야산, 덕유 산, 지리산 집단의 경우 모두 마가목형(commixta type)으 로 확인되는 반면, 한반도당마가목은 대부분 wilsoniana type으로 뚜렷하게 구분이 되어 실제 형태적으로는 종간 잡종의 증거는 직접적으로 찾기 어려워 Coreopsis형에 더 가깝다(Fig. 6).

식물지리학적 고려: 마가목속은 화석기록이 없어 과거 의 분포를 알기가 쉽지 않지만, 신생대 제 3기(Tertiary) 마 이오신(Miocene) 또는 플리오신(Pliocene) 시기에 북미대륙 과 아시아 사이에서 분화된 마가목(S. commixta)이 사할린 과 일본에 분포한 것으로 보고 있다(McAlister, 2005). 신생 대 제4기(Quarternary)에는 여러 번의 빙기와 간빙기가 반 복 되면서 이 기간 동안 해수면의 하강으로 중국대륙과 한 반도 및 일본이 육지로 연결되어 많은 식물들이 중국 및 일 본으로부터 한반도로 유입되었다(Winkler and Wang, 1993).
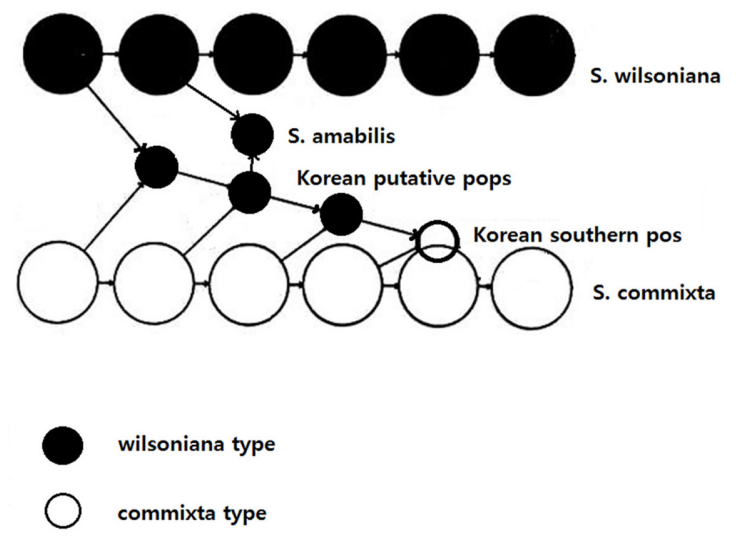

Fig. 6. Proposed hypothesis of introgressive hybridization between Sorbus commixta and S. wilsoniana and between $S$. wilsoniana and S. amabilis.

화학적, 형태적 자료를 종합하여 가설을 설정해 보면 중 국 내륙의 윌슨마가목이 한반도내에 1 차 유입되어 이미 일본으로부터 유입된 마가목과 잡종이 되었지만, 이후 월 슨마가목이 한반도에서 멸절되었을 가능성이 높다. 이후, S. wilsoniana x S. commixta의 교잡개체는 한반도내에 잔존 하던 마가목과 반복적인 교잡이 되면서 점차적으로 잡종 이입(introgressive hybridization)이 진행되었을 것으로 추측 된다. 이런 이유로 한반도당마가목의 실체는 점점 형태적 으로 마가목과 유사한 형태를 가졌다고 본다.

그러나, 특정 시기에 한반도 당마가목은 남쪽에서 멸절 된 이후, 일본이나 제주도에서 2 차 유입되어 현재의 가야 산, 덕유산, 지리산 등지의 집단이 형성된 것으로 추정한 다. 한편, 중국 동부에 분포하면서 마가목의 유연관계가 높은 종으로 보는 S. amabilis는 한반도 당마가목과 특정시 기에 교잡되었지만, 지속적인 윌슨마가목과 잡종이입에 의해 현재의 실체가 형성되었을 것으로 판단된다. $S$. amabilis는 윌슨마가목의 이명으로 보나 본 연구에서는 관 찰표본의 부족으로 분류학적 처리는 시도하지 않았다.

한반도의 주요 형성 식물상은 만주구계로도 불리는 북 방 계열인 백두대간 식물상(Amur flora)과 한일구계로 불 리는 남방계열이 주로 구성되면서 상호 잡종이 지사적으 로 오랜 시간에 걸쳐 형성이 되었다. 기존 잡종과 관련된 형태학적인 연구 제시는 한반도와 러시아, 일본 등지에서 과거 잡종의 근거(Quercus mongolica complex, Q. variabilis Blume, Okura et al., 2007; Zeng et al., 2011; Chen et al., 2012), 북방계열의 분비나무와 남방계열의 구상나무의 예(Abies koreana E.H. Wilson, Chang et al., 2000), 백두대간의 지렁쿠 나무와 남쪽의 덧나무(Sambucus racemosa complex, Lim et al., 2009), 북방계통의 물개암나무와 남방계통의 참개암 나무의 예(Corylus sieboldiana complex, Chang et al., 2004) 가 있지만, 일부는 중국 내륙에서 한반도로 유입된 후 고 립된 경우도 있는데 울릉도의 너도밤나무(Fagus engleriana Seemen ex Diels, Fu et al., 2000), 섬개야광나무 
(Cotoneaster multiflorus Bunge, Chang and Jeon, 2003)가 그 예이다. 이와는 반대로 한반도에서 일본으로 유입된 가문 비나무(Aizawa et al., 2007)와 한반도와 일본 혹은 중국과 격리되어 독립적인 계통 관계를 보여주는 나도승마 (Kirengeshoma palmata Yatabe, Qiu et al., 2009)와 히어리 (Corylopsis coreana Uyeki, unpublished data)의 경우 등 종간 의 매우 다양한 연구 결과가 기존에 언급된다.

한반도 내륙에서 확인되는 특이한 화학형의 한반도당 마가목은 북방계열인 중국 동북3성(흑룡, 길림, 요녕)과 러시아 아무르(Amur)지역의 당마가목(Sorbus pohuashane$n s i s)$ 과 달리 중국 내륙의 윌슨마가목에 보다 가까운 유연 관계를 보였다. 본 연구 결과 당마가목(S. pohuashanensis) 은 신생대 제4기(Quarternary) 유럽대륙의 S. aucuparia가 유라시아를 통해 중국 북부와 극동러시아까지 퍼져 분화 된 분류군으로 광범위하게 분포하는 S. aucuparia에서 분 화된 근연종으로 보는 것이 타당하며 국내에는 백두산에 국한해서 분포하는 것으로 본다(McAllister, 2005).

기존의 잡종이입과 관련된 연구 결과에 의하면 유전다 양성의 증가, 새로운 형태의 출현이나 적응, 생식적 격리 등이 있으며 대부분 분자 연구에 의해 기작이 규명되지만 본 연구에서처럼 과거 지사적 과정은 대부분 규명하기 어 렵고(cryptic) 계통학적으로도 해석이 불가능한 경우도 발 생하며(Howard, 1993; Baumel et al., 2002; Cronn et al., 2003), 특히, 동아시아에 분포하는 일부 분류군 사이에는 매우 활발한 잡종현상이 일어나 종간 식별의 정량적인 형 질을 찾기가 어렵다. 정성적 형질의 경우 한반도당마가목 은 동아의 형태만 중국 및 러시아에 분포하는 당마가목과 달리 일본, 러시아의 사할린까지 분포하는 마가목이나 중 국 내륙의 윌슨마가목, S. amabilis와 가깝게 나타났으며, 나머지 탁엽, 자방의 특징은 마가목과 일치하여, 전체적 으로 일본의 마가목에 더 가까운 정성적 형질을 가지고 있다. 마가목의 경우 식물 구계로는 중국남부/한일 구계 에 속하며 일본에서 기원한 것으로 판단돼서, 통상 과거 북방과 남방계열로 구분된 식물상의 해석과 달리, 본 연 구 대상의 식물은 중국 내륙과 남방계열과의 잡종으로 본 다(Chang et al., 2011).

교잡에 의한 잡종은 중국 내륙에서 볼 수 있는 윌슨마가 목의 동아의 갈색털이 존재하거나, 혹은 짙은 갈색의 동 아 아린을 제외하고는 정량적이거나 정성적으로 마가목 과 별다른 차이점을 확인할 수 없어, 현재의 전형질적 종 의 개념(phenetic species concept)으로 마가목과 동일종으 로 보았다(Henderson, 2006; Mallet, 2007).

분자분류학적 차원에서 마커에 의한 S. wilsoniana $\mathrm{x} S$. commixta의 잡종과 잡종이입의 직접적인 증거자료를 찾 아 역사적 종의 개념(historical species concept; Luckow, 1995; Mallet, 2007)에 근거하여 새로운 잡종의 종기재 (nothotaxa)가 가능하다고 보나, 본 연구는 기존 국내 당마 가목과 관련된 분류군은 모두 마가목의 이명으로 보고 분
류학적 처리를 제시하였다(예, 사시나무속, Barnes and Han. 1993).

본 연구결과 마가목은 한반도 대부분 집단에 분포하는 실체로 보며, 북한에 분포하는 외국 소장 표본의 화학 분 석결과 당마가목은 중국 동북3성과 극동러시아 및 백두 산에만 분포하는 것으로 확인되었다. 또한, 울릉도 집단 의 경우에는 신종(Sorbus ulleungensis Chin S. Chang)으로 판단되어 신종기재를 하였으며, 본 논문에 검색표에 포함 을 하였다(Park et al., 2013, in press).

\section{검색표}

1. 탁엽은 부채꼴이며 숙존성이다; 열매의 심피가 완전 히 분리됨; 소엽 뒷면에는 대부분 흰털 혹은 갈색털 이 존재한다; 동아는 짙은 갈색, 갈색 혹은 흰 털이 존 재; 소엽수는 9-17개

2. 소엽수 (11)13-15(17)개, 소엽은 털이 없거나 갈색털 이 있다; 동아는 암갈색을 띄며 동아 선단부에 갈색 털이 밀생하며 점성이 존재; 중국(Guangxi, Guizhou, Hubei, Hunan, Sichuan, Yunnan, Anhui, Zhejiang, Fujian) …………….......................... S. wilsoniana

2. 소엽수 9-11개, 소엽은 흰털이 있다; 동아색이 검고, 동아 표면에 흰 털이 밀생하며 점성이 없다; 중국 (Liaoning, Jilin, Heilongjiang), 극동러시아, 한반도 함 경북도 백두산 S. pohuashanensis

1. 탁엽은 침형이고 일찍 탈락(낙엽성)한다; 열매의 심 피는 분리되어 있으나 밑부분이 약간 합생함; 소엽 뒷면에 털이 거의 없다; 동아는 붉은 색이며 털이 거 의 없거나 정단부분에 일부 존재(한반도 개체는 검 은색도 존재); 소엽수는 9-11개

3. 꽃 직경은 $8-11 \mathrm{~mm}$; 열매의 크기는 $6.4-7.9 \mathrm{~mm}$; 소엽 수는 9-13개; 암술대 3-4개; 수피는 연한 갈색; 일본, 극동러시아 Sachaline, 한반도 전체 (백두산제외)

S. commixta

3. 꽃 직경은 $12-14 \mathrm{~mm}$; 열매의 크기는 9.0-10.5 mm; 소엽수는 $13-15$ 개; 암술대는 3-5개; 수피는 짙은 갈 색; 울릉도 S. ulleungensis

Taxonomic Treatments of Sorbus pohuashanensis and $S$. commixta

Sorbus pohuashanensis (Hance) Hedl., Kongl. Svenska Vetensk. Acad. Handl. 35: 33, 1901.

Pyrus pohuashanensis Hance, J. Bot. 13: 132, 1875. Type. China. Pohuashan, June, 1874, Bretschneider 160; China. Pohuashan, May, 1874, Bretschneider 18423 (BM!, seen as a photo)

Sorbus amurensis Koehne, Repert. Spec. Nov. Regni Veg. 10: 513, 1912; Sorbus pohuashanensis var. amurensis (Koehne) 
Y.L. Chou \& S.L. Tung, Ligneous Fl. Heilongjiang 335, 1986. Type. Russia. Amur, Maximowicz s.n. (LE?, K!, seen as a photo).

Sorbus manshuriensis Kitag., J. Jap. Bot. 22: 175, 1948; Sorbus pohuashanensis var. manshuriensis (Kitag.) Y.C. Zhu Pl. Medic. Chinae Bor. Orient.558, 1989. Type. China. Prov. Tung-hua(通化=吉林，Jilin): Hua-pihe-tzu(樺皮河子)，26 July, 1940, M. Kitagawa s.n. (holotype, KYO, not seen).

Distribution: Far eastern Russia, China (Liaoning, Jilin, Heilongiiang, Nei Mongo), Korea (Mt. Baekdu-san)

Korean name: Dangmagamok 당마가목

Sorbus commixta Hedl., Kongl. Svenska Vetensk. Acad. Handl. 35: 38, 1901.

Sorbus aucuparia var. japonica Maxim., Mélanges Biol. Bull. Phys. Math. Acad. Imp. Sci. Saint-Pétersbourg 9: 170, 1874; Sorbus japonica (Maxim.) Koehne, Gartenflora 408, 1901. Type. Japan. Fudzi yama, in Tsusima (=Tsushima), unknown date, 1859, C. Wilford s.n. (K!, seen as a photo).

Sorbus reflexipetala Koehne, Mitt. Deut. Dendrol. Ges. 15 58, 1906. Type. unknown.

Sorbus commixta f. angustissima C.K. Schneid., Bull. Herb. Boissier ser. 2, 6: 314, 1906. Type. Japan. Jesso (=Hokkaido), Shiretoko, Faurie 10944 (E?, Syntype, not seen).

Sorbus commixta var. rufoferruginea C.K. Schneid., Bull. Herb. Boissier ser. 2, 6: 315, 1906; Sorbus rufoferruginea (C. K. Schneid.) C. K. Schneid. Ill. Handb. Laubholzk. 2:996, 1912. Type. Japan. Jesso (= Honshu, Nagano Pref.), Asamayama, Faurie 379, Faurie 380, (E?, B?, Syntype, not seen)

Sorbus pruinosa Koehne, Repert. Spec. Nov. Regni Veg. 10: 506, 1912. Type. Russia. Sachalin: Kasankokan, 14 Sept. 1861, Glehn s.n. (B?, not seen).

Sorbus heterodonta Koehne, Repert. Spec. Nov. Regni Veg. 10: 506, 1912. Type. Japan. Provinz Shinano(=Nagano), Mstsushiro, Sept. 1885, Saida s.n. (B?, not seen).

Sorbus amurensis var. lanata Nakai, Bot. Mag. (Tokyo) 30: 17, 1916. Type. in silvis Corea sept. [Korea. Hamkyongbukdo, Musan-gun, Nongsa-dong to Samha-meon (咸北茂山郡 農事 洞-三下面)], Aug. 14, 1914, T. Nakai s.n. TI; Hamkyongnamdo, Jangjin-gun, Gangku (咸南 長津郡 江口), July 22, 1914, T. Nakai s.n. (syntype, TI, not seen).

Sorbus commixta var. pilosa Nakai, Fl. Sylv. Kor. 6: 23,1916. Type. Korea.in silvis montis Chirisan. rara! [Kyongsangnamdo: Mt. Jiri-san, Yongshin (慶南 智異山 神境), June 7, 1913, T. Nakai s.n. (holotype, TI, not seen).

Sorbus commixta var. sachalinensis Koidz., Bot. Mag. (Tokyo) 31: 137, 1917. Type. Russia. Sachaline, unknown (TI, not seen).

Sorbus amurensis var. rufa Nakai, Bot. Mag. (Tokyo) 33: 57, 1919. Type. Korea. in silvis montis Yukokurei (Hamkyongbuk-do: Kyongsung-gun, Jueolon-meon, Taegokryong, 咸北 鏡城郡 朱乙溫面 態谷嶺), July 18，1918，T. Nakai 7143 (holotype, TI, not seen).

Sorbus chionophylla Nakai, J. Jap. Bot. 15: 677, 1939. Type. Korea. Prov. Tyuhoku: in silvis cirrea templum Fukusen-an (= Chungcheonbuk-do, Bokcheonam, 忠北 福泉庆), Aug. 16, 1934, T. Nakai 14976 (holotype, TI, not seen).

Sorbus amurensis var. latifoliolata Nakai, J. Jap. Bot. 17: 192, 1941; Sorbus amurensis f. latifoliolata (Nakai) W.T. Lee, Lineamenta Florae Koreae 541, 1996. Type. Korea. Prov. Keihoku: in silvis montis Nanzan montium Kayasan (Kyonsangbuk-do, Namsan, Gayasan, 慶北 南山 伽㑡山), Aug. 12, 1939, T. Nakai 18356 (holotype, TI, not seen).

Distribution: Korean peninsula (excluding Mt. Baekdu-san and Ulleung Island), Japan, Far eastern Russaia (Sachaline)

Korean name: Magamok 마가목

\section{사 사}

본 연구는 교과부 연구재단(NRF, No. 2011-0022323)로 수행되었으며, 지원에 감사드립니다. 본 연구를 위해 표 본 대여와 관찰을 허락한 표본관에 감사를 표합니다.

\section{인용문헌}

Aizawa, M., H. Yoshimaru, H. Saito, T. Katsuki, T. Kawahara, K. Kitamura, F. Shi, M. Kaji, J. H. Browun and M. V. Lomolino. 2007. Phylogeography of a northeast Asian spruce, Picea jezoensis, inferred from genetic variation observed in organelle DNA markers. Molecular Ecolology 16: 3393-3405.

Baumel, A., M. L. Ainouche, R. J. Bayer, A. K. Ainouche and M. T. Misset. 2002. Molecular phylogeny of hybridizing species from the genus Spartina Schreb (Poaceae). Molecular Phylogenetics and Evolution 22: 303-314,

Barnes, B. V. and F. Han. 1993. Phenotypic variation of Chinese aspens and their relationships to similar taxa in Europe and North America. Canadian Journal of Botany 71: 799-815.

Campbell, C. S., R. C. Evans, D. R. Morgan, T. A. Dickinson and M. P. Arsenault. 2007. Phylogeny of subtribe Pyrinae (formerly the Maloideae, Rosaceae): Limited resolution of a complex evolutionary history. Plant Systematics and Evolution 266: 119-145.

Chang, C. S., J. I. Jeon and H. Kim. 2000. A systematic reconsideration of Abies korena Wilson using flavonoids and allozyme analysis. Korean Journal of Plant Taxonomy 30: 215-234. 
(in Korean)

Chang, C. S. and J. I. Jeon. 2003. Leaf flavonoids in Cotoneaster wilsonii (Rosaceae) from the island Ulleung-do, Korea. Biochemical Systematics and Ecology 31: 171-179.

Chang, C. S., G. S. Chang and H. N. Qin. 2004. A multivariate morphometric study on Corylus sieboldiana complex (Betulaceae) in China, Korea, and Japan. Acta Phytotaxonomica Sinica 42: 222-235.

Chang, C. S., H. Kim and K. S. Chang. 2011. Illustrated Encyclopedia of Fauna \& Flora of Korea. Design Post, Paju. (in Korean)

Charkevicz, S. S. 1996. Plantae Vasculares Orientis Extremi Sovietici. Tomus 8. Leningrad, Saint Petersburg. (in Russian)

Chen, D., X. Zhang, H. Kang, X. Sun, S. Yin, H. Du, N. Yamanaka, W. Gapare, H. X. Wu and C. Liu. 2012. Phylogeography of Quercus variabilis Based on Chloroplast DNA Sequence in East Asia: Multiple Glacial Refugia and Mainland-Migrated Island Populations. PLOS ONE 7: 1-14.

Cronn, R., R. L. Small, T. Haselkorn and J. F. Wendel. 2003. Cryptic repeated genomic recombination during specieation in Gossypoium gossypiodies. Evolution 57: 2475-2489.

Crawford, D. J. 1970. Systematic studies on Mexican Coreopsis (Compositae) Coreopsis Mutica: Flavonoid chemistry, chromosome numbers, morphology, and hybridization. Brittonia 22: 93-111.

Fu, L. K., T. Q. Chen, K. Y. Lang, T. Hong and Q. Lin. 2000. Higher Plants of China Vol. 4. Qingdao Publishing House, Qingdao. (in Chinese)

Fu, L. K., T. Q. Chen, K. Y. Lang, T. Hong and Q. Lin. 2003. Higher Plants of China Vol. 6. Qingdao Publishing House, Qingdao. (in Chinese)

Gil, H. Y. 2013. Taxonomic study of the Sorbus commixta complex in Eastern Asia : flavonoids and morphological analyses. MS thesis, Department of Forest Sciences, Seoul National University, Seoul. (in Korean)

Giannasi, D. E. and D. J. Crawford. 1986. Biochemical systematics II. A reprise. Evolutionary Biology 20: 25-248.

Harborne, J. B. and B. L. Turner. 1984. Plant Chemosystematics. Academic Press, London.

Henderson, A. 2006. Morphometrics in palm systematics. Botanical Journal of the Linnean Society 151: 103-111.

Howard, D. J. 1993. Reinforcement:origin, dynamics, and fate of an evolutionary hypothesis. In Hybrid Zones and the Evolutionary Process. Harrison, R. G. (ed.), Oxford University Press, New York. Pp. 46-69.

Huh, M. K., S. Kim and S. H. Park. 2007. Phylogenetic study of genus Sorbus in Korea by Internal Transcribed Spacer Sequence (ITS). Journal of Life Science 17: 1610-1615.
Iwatsuki, K., D. E. Boufford and H. Ohba (eds.). 2001. Flora of Japan Volume b Angiospermae-Dicotyledoneae: Archichlamydeae (b). Kodansha LTD, Tokyo.

Jauhar, P. P. and A. B. Joshi. 1970. The concept of species and "microspecies" Taxon 19: 77-79.

Kim, S. H., Y. S. Jang, H. G. Chung, H. S. Park and K. J. Cho. 2003. Leaf morphological characteristics of Sorbus commixta Hedl. selected populations. Journal of Korean Forestry Society 92: 488-496.

Kim, S. H., Y. S. Jang, J. G. Han, H. G. Chung, H. W. Seo and I. H. Park. 2007a. Leaf characteristics and genetic relationships analysis among four species in the genus Sorbus. Korean Journal of Breeding Science 39: 427-434. (in Korean)

Kim, S. H., Y. S. Jang, J. G. Han, H. W. Seo, I. H. Park and K. J. Cho. 2007b. Investigation on the genetic relation of Sorbus species by multivariate analysis and DNA polymorphism. Korean Journal of Breeding Science 39: 178-186.

King, B. L. 1977. The flavonoids of the deciduous Rhododendron of North America (Ericaceae). American Journal of Botany 64: 350-360.

Koehne, E. 1913. Sorbus, In Plantae Wilsonianae Vol. 1(3). Sargent, C. S. (ed.), Cambridge University Press, Cambridge, Pp. 457-483.

Krüssmann, G. 1984. Manual of Cultivated Broad-leaved Trees \& Shrubs: Vol. 3 (Pru-Z). Timber Press, Portland.

Kurata, S. 1971. Illustrated Important Forest Trees of Japan. Vol.1. Chikyu Shuppan, Tokyo. (in Japanese)

Lee, T. B. 1980. Illustrated Flora of Korea. Hyangmun Co., Seoul. (in Korean)

Lim, H. I., K. S. Chang, H. S. Lee, C. S. Chang and H. Kim. 2009. A reappraisal of Sambucus pendula Nakai on Ulleung Island and its allies. Korean Journal of Plant Taxonomy 39: 181-192. (in Korean)

Lu, L. and S. A. Spongberg. 2003. Sorbus, In Flora of China. Vol. 9 (Pittosporaceae Through Connaraceae). Wu, Z. Y., P. H. Raven and D. Y. Hong (eds.), Science Press, Missouri Botanical Garden Press, Beijing, St. Louis, Pp. 144-170.

Luckow, M. 1995. Species concepts: assumptions, methods, and applications. Systematics Botany 20: 589-605.

McAllister, H. 2005. The genus Sorbus: mountain ash and other rowans. Royal Botanic Gardens, Kew.

Mallet, J. 2007. Species, concepts of. In Encyclopedia of Biodiversity. Levin, S. et al. (eds.), Online update Elsevier, Oxford 1, Pp. 1-15.

Nakai, T. 1916. Flora Sylvatica Koreana. Vol. 6. Forest Experimental Station of Chosen Government, Seoul.

Nitzelius, T. G. 1989. The Ullung Rowan. Supplement till Lustgården 1989. 
Ohwi, J. 1984. Flora of Japan. Smithsonian Institution, Washington, D.C.

Okaura, T., N. D. Quang, M. Ubukata and K. Harada. 2007. Phylogeographic structure and late Quaternary population history of the Japanese oak Quercus mongolica var. crispula and related species revealed by chloroplast DNA variation. Genes \& Genetic Systems 82: 465-477.

Park, S. H., S. H. Kim, H. W. Seo and M. K. Huh. 2007. Study of genetic diversity and taxonomy of genus Sorbus in Korea using random amplified polymorphic DNA. Journal of Life Science 17: 470-475.

Park, S. K., H. Y. Gil and C. S. Chang. 2013. Sorbus ulleungensis, a new endemic species on Ulleung Island, Korea. Harvard Papers in Botany 18(2) (in press).

Qiu, Y. X., Y. Sun, X. P. Zhang, J. K. Lee, C. X. Fu and H. P. Comes. 2009. Molecular phylogeography of East Asian
Kirengeshoma (Hydrangeaceae) in relation to Quaternary climate change and landbridge configurations. New Phylogist 183: 480-495.

Robertson, K. R., J. B. Phipps, J. R. Rohrer and P. G. Smith. 1991. A synopsis of genera in Maloideae (Rosaceae). Syst. Bot. 16: 376-394.

Winkler, M. G. and P. K. Wang. 1993. The Late-Quaternary vegetation and climate of China, In Global Climates Since the Last Glacial Maximum. Wright, J. E., Kutzbach, T. Webb, W. F. Ruddiman, S. F. Alayne and P. J. Bartlein (eds.), University of Minnesota Press, Minneapolis.

Zeng, Y. F., W. J. Liao, R. J. Petit and D. Y. Zhang. 2011. Geographic variation in the structure of oak hybrid zones provides insights into the dynamics of speciation. Molecular Ecology 20: 4995-5011. 